\title{
USING A NEW PROTEIN SOURCES IN FEEDING OF RUMINANTS \\ 1- EFFECT OF FEEDING DIFFERENT LEVELS OF GUAR KORMA AS A SOURCE OF PROTEIN ON THE PRODUCTIVE PERFORMANCE OF EGYPTIAN BUFFALOES. \\ Etman, K.E.; Ebtehag I. M. Abou-Elenin; T.I. El-Monayer and F.A. El-Sayed. \\ Animal Production Research Institute, Agricultural Research Center, Cairo, Egypt
}

\begin{abstract}
This work aimed to use guar korma meal in concentrate feed mixture(CFM) for growing buffalo calves rations. The trial was carried out at Animal House of Animal production Research Institute and Al-Manar Company Station. Thirty male buffalo calves averaging $176.9 \mathrm{Kg}$ LBW were chosen and divided into six similar groups. The groups of animals were randomly assigned to receive six experimental rations containing CFM which included guar Korma at the rate of $0,3.3,6.7,10.0,13.3$ and $16.7 \%$ in rations $A, B, C, D, E$ and $F$, respectively. These percentages of guar korma cover $0,10,20,30,40$ and $50 \%$ of CFM protein content. All animals received CFM, berseem hay $(\mathrm{BH})$ and wheat straw (WS) at the rate of 70:20:10, respectively.

The feeding trial lasted 210 days, during which live body weights were recorded beside feed intake. Economical efficiencies were calculated for each ration. In addition, six digestibility trials were conducted to determine digestibility and nutritive values of the experimental rations. Samples of blood were taken to measure some blood parameters.

The results obtained can be summarize as follows:

1) The chemical composition of different experimental rations were almost similar in DM, OM, CF,CP and NFE contents, with somewhat higher percentage of EE and Ash associated with increasing guar korma levels.

2) Increasing guar korma level in the experimental rations tended to significantly $(P<0.05)$ increase DM, OM, CP,EE and CF digestibilities, while the difference in NFE digestibility was not statistically significant. In addition, there were significant $(\mathrm{P}<0.05)$ increase in TDN and DCP with increasing guar korma levels in the rations, especially in ration $\mathrm{F}$, which had $70.82 \%$ TDN and $10.99 \%$ DCP.

3) Average total protein and albumin were significantly $(P<0.05)$ higher for ration $D, E$, and $\mathrm{F}$, while differences in globulin were not significant. Also, AST (Aspartate amino transferase) and ALT (Alanin amino transferase) concentrations significantly $(P<0.05)$ increase for ration $E$ and $F$, while differences in kidney functions parameters were not significant.

4) Average daily LBW gains significantly $(P<0.05)$ increased with increasing guar korma levels in the rations, being $1.296,1.325,1.357,1.392,1.425$ and $1.475 \mathrm{~kg}$ for animals given rations $A, B, C, D, E$ and $F$, respectively. At the same time, the best improvement in feed utilization efficiency expressed as $\mathrm{kg}$ DM or TDN per kg gain was recorded for ration $\mathrm{F}$ which contain the highest level of guar korma, being 7.935 and 5.620 , respectively.

5) Average feed cost/kg weight gain decreased with increasing guar korma levels in the rations, being $18.870,18.227,17.429,16.650,15.822$ and 15.249 LE with rations $A, B, C, D, E$ and $F$, respectively. Moreover, revenue, gross margin above feed cost, profit and economical efficiency showed the highest values for ration $F$,
\end{abstract}


being 9.958 LE, 0.443 LE, $44.27 \%$ and 1.443 , respectively. The highest improvement in economical efficiency was recorded also for ration $F(23.76 \%)$ which contained the highest level of guar korma.

From the previous results it could be concluded that, guar korma meal can be used as a source of protein in ration formulation of growing buffalo calves. Using guar korma meal to cover $50 \%$ protein of CFM of growing buffalo calves rations increased digestibility of most of nutrients, daily gain, and decreased feed cost $/ \mathrm{kg}$ gain, in addition to revenue and economical efficiency. Blood parameters were not affected by guar korma and they within normal ranges without any side effects.

\section{INTRODUCTION}

Guar korma is a by-product obtained after processing guar seeds. The processed guar korma is usually rich in protein and carbohydrate and thus forms a high protein feed for ruminants and other animals. It is used mainly to feed the milking animals to increase milk and milk fat percentage of fat in milk, beside being a good feed of beef animals.

Guar korma is generally cheaper feed ingredient than soybean meal, dried distiller grains and cotton seed cake and therefore used as substitute for those traditional meals in feeding animals.

The by-product of guar gum industry consisting of the outer seed coat and germ material is called guar meal. The guar meal after gum extraction is a potential source of protein and contains about 35 to $47 \%$ crude protein, which is one and a half times the level of protein in guar seed (Altrafine gum, 2011).

Guar meal is a $100 \%$ natural agricultural product and is rich in protein and carbohydrate suitable for feeding ruminants and livestock. It has highprotein content and is produced during extraction of galactomannan gum from the guar beans. During the extraction process, two fractions are produced (germ and hull). The germ and hull fractions are usually combined to form the marketed product which called guar meal. Guar meal typically comes in two forms :(a) Guar meal churi, which is a powder and (b) Guar korma meal which is a granular form and their average composition is $38 \%$ $\mathrm{CP}, 7 \% \mathrm{EE}, 10 \%$ moisture, $6 \% \mathrm{CF}$ and $1 \%$ silica for guar meal churi, while the corresponding values for guar korma meal are $50 \% \mathrm{CP}, 7 \% \mathrm{EE}$, 8\% moisture, 5\% CF and 1\% silica (Srivastava et al.,2011).

The objective of this work was to study the effect of using different levels of guar korma meal in ration formulation of growing buffalo calves on nutrient digestibility, productive performance and economical efficiency.

\section{MATERIALS AND METHODS}

The experiment work was carried out at Animal House of Animal Production Research Institute, Agriculture Research Center and Al-Manar company station, Masr-Alex. Desert road. Thirty male buffalo calves averaging $176.9 \mathrm{~kg}$ LBW were chosen and divided into six similar groups (5 in each). The groups of animals were randomly assigned to receive six experimental rations containing concentrate feed mixture which included guar 
korma at the rate of $0,3.3,6.7,10.0,13.3$ and $16.7 \%$ in rations $A, B, C, D, E$ and $\mathrm{F}$, respectively. The previous percentage of guar korma covered $0,10,20,30,40$ and $50 \%$ of protein for CFM of the respective rations. All animals received CFM, berseem hay and wheat straw at the rate of 70:20:10, respectively according to Abou Raya (1967). CFM were given to animals at 8.00 a.m. and 3.00 p.m. followed by berseem hay, while wheat straws were available all day. All experimental rations were isonitrogenous and isoenergetic. The feeding trial lasted 210 day during which changes in live body weight and feed intake were recorded. At the middle of feeding trial, six digestibility trials were carried out using 3 calves in each treatment to determine digestibility coefficients and feeding values of the experimental rations. Samples of feed and excreta were collected to be analyzed according to A.O.A.C. (2000). At the same time, blood samples were taken from animals in the digestibility trials to determine total protein and albumin according to Cornell et al., (1949) and Drupt (1974), respectively, while globulins were determine by differences. Creatinine and urea- $\mathrm{N}$ were determined for kidney function as described by Young (1990) and Fawcett and Scott (1960). On the other hand, AST and ALT concentrations were determined according to Reitman and Frankel (1957) for liver function. Data were statistically analyzed by using general linear model (GLM) procedure according to Statistical Analysis System (SAS, 2000), while differences among means were tested using Duncan Multiple range test (Duncan, 1955).

\section{RESULTS AND DISCUSSION}

Large number of feedstuffs could be used as protein source in ruminant feeding such as decorticated and undecorticated cotton seed meals, undecorticated sunflower meal, corn gluten feed, dried distiller grain with solubles (DDGS) and soybean meal. There feedstuffs had high protein contents, being $41,26,28,62,29.1$ and $44 \%$, respectively, while guar korma had higher protein content $(50 \% \mathrm{CP})$ except for corn gluten which contains $60 \%$ protein, as shown in Table (1). Moreover, guar korma contain lower CF content $(6.7 \%)$ with somewhat higher NDF content $(42 \%)$. Also, guar korma had higher calcium, total phosphorus and available phosphorus percentages, being $1.8,0.74$ and $0.23 \%$, respectively, as showed in Table (1).

Also, guar korma had the highest lysine percentage, being $3.00 \%$ versus 1.60, 1.00, 1.00, 1.00, 0.20 and $2.95 \%$ for decorticated, undecorticated cotton seed meal, undecorticated sunflower meal, corn gluten feed, dried distiller grain with soluble and soybean, respectively. Also, amino acid tryptophan content of guar korma showed the same previous trend, recording the highest percent $(0.90 \%)$ compared to the others. In addition, the energy values expressed as DE ( $\mathrm{kcal} / \mathrm{kg})$ and TDN (\%) were the highest values of guar korma, showing $3880 \mathrm{kcal} / \mathrm{kg}$ as DE and $86 \%$ as TDN.

Additionally, guar korma had higher value of methionine compared to those of other feedstuffs, being $2.96 \%$ while lysine, glycine, arginine and tryptophan were $2.56,5.85,9.96$ and $0.52 \%$, respectively. 
Table (1): Feed composition of some different protein sources used in animal feeding*.

\begin{tabular}{|c|c|c|c|c|c|c|c|}
\hline \multirow[b]{2}{*}{ Items } & \multicolumn{7}{|c|}{ Different protein sources } \\
\hline & $\begin{array}{l}\text { Decorti- } \\
\text { cated } \\
\text { Cotton } \\
\text { seed } \\
\text { meal }\end{array}$ & $\begin{array}{l}\text { Undecorti- } \\
\text { cated } \\
\text { cotton } \\
\text { seed } \\
\text { meal }\end{array}$ & $\begin{array}{l}\text { Undecor- } \\
\text { ticated } \\
\text { sunflower } \\
\text { meal }\end{array}$ & $\begin{array}{c}\text { Corn } \\
\text { gluten } \\
\text { feed } \\
(60 \%)\end{array}$ & $\begin{array}{c}\text { Dried } \\
\text { distiller } \\
\text { grain } \\
\text { with } \\
\text { soluble } \\
\text { (DDGS) }\end{array}$ & $\begin{array}{c}\text { Guar } \\
\text { korma } \\
\text { meal }\end{array}$ & $\begin{array}{c}\text { Soy } \\
\text { bean } \\
\text { meal } \\
(44 \%)\end{array}$ \\
\hline Proximate analysis (\%): & & & & & & & \\
\hline$\overline{\mathrm{DM}}$ & 91 & 90 & 89 & 90 & 90 & 90 & 87 \\
\hline $\mathrm{CP}$ & 41 & 26 & 28 & 62 & 29.1 & 50 & 44 \\
\hline $\begin{array}{l}\text { EE } \\
\text { Fiber }(\%) \text { : }\end{array}$ & 1.5 & 1.5 & 2.0 & 2.2 & 9.8 & 6 & 1.5 \\
\hline$\overline{\mathrm{CF}}$ & 14 & 24 & 25 & 2.0 & 8.5 & 6.7 & 7.3 \\
\hline ADF & 18 & 28 & 30 & 5.0 & 21 & 22 & 10 \\
\hline NDF & 27 & 40 & 40 & 13 & 46 & 42 & 15 \\
\hline $\begin{array}{l}\text { Ash } \\
\text { Minerals (\%): }\end{array}$ & 6.4 & 5.0 & 6.2 & 1.6 & 4.5 & 5.0 & 6.5 \\
\hline$\overline{\mathrm{Ca}}$ & 0.20 & 0.27 & 0.34 & 0.07 & 0.21 & 1.80 & 0.30 \\
\hline Total P & 1.00 & 0.76 & 1.00 & 0.48 & 0.83 & 0.74 & 0.65 \\
\hline $\begin{array}{l}\text { Avi P } \\
\text { Amino Acids (\%): }\end{array}$ & 0.29 & 0.18 & 0.28 & 0.19 & 0.56 & 0.23 & 0.27 \\
\hline$\overline{\text { Lysine }}$ & 1.60 & 1.00 & 1.00 & 1.00 & 0.20 & 3.00 & 2.95 \\
\hline Methionine & 0.55 & 0.26 & 0.65 & 1.70 & 0.51 & 0.60 & 0.65 \\
\hline Methionine +Cys. & 1.20 & 0.59 & 1.35 & 2.80 & 0.60 & 1.02 & 1.34 \\
\hline Thrionine & 1.20 & 0.79 & 1.00 & 2.20 & 0.92 & 1.80 & 1.80 \\
\hline $\begin{array}{l}\text { Tryptophane } \\
\text { Energy Value: }\end{array}$ & 0.50 & 0.35 & 0.40 & 0.30 & 0.20 & 0.90 & 0.56 \\
\hline$\overline{\mathrm{GE}(\mathrm{kcal} / \mathrm{kg})}$ & 4280 & 3487 & 4180 & 4900 & 4415 & 4050 & 4150 \\
\hline $\mathrm{DE}(\mathrm{kcal} / \mathrm{kg})$ & 3170 & 2650 & 2200 & 3570 & 3620 & 3880 & 3200 \\
\hline $\operatorname{TDN}(\%)$ & 72 & 60 & 50 & 81 & 82 & 86 & 75 \\
\hline
\end{tabular}

${ }^{*}$ Cited from : (1)Technical Bulletin, Central Lab for Food and Feed, NO.1, 2001, Egypt (2)Church (1984)

Generally, using guar korma as a source of protein in ruminant feeding might be attributed to its high palatability and high CP content. Moreover, it contains $\mathrm{Ca} \%$, total phosphorus, available phosphorus and lysine beside its higher DE $(\mathrm{kcal} / \mathrm{kg})$ and TDN\% values. Therefore guar korma might improve its intake and digestibility to become more efficiently be utilized by the animals. Some authors used guar korma meal in feeding animals, Turki et al., (2011), Farkhanda et al., (2006), Ahmed et al., (2000), Sehgal and Makker (1994) and Saleh pour et al., (2012). They showed that the guar korma could be used as an ingredient in animal rations with no adverse effect.

\section{Incorporation of guar korma in concentrate feed mixture of} experimental rations:

Data presented in Table (2) showed the ingredients of concentrate feed mixture of different experimental rations, which included guar korma with rate of $0,3.3,6.7,10.0,13.3$ and $16.7 \%$ in $1,2,3,4,5$ and 6 concentrate feed mixture (CFM), respectively. Guar korma was as a source of protein and covered $0,10,20,30,40$ and $50 \%$ crude protein of CFM for rations A,B,C,D,E and $F$, respectively. It could be noticed that, the guar korma amounts were 
replaced partially of totally both cotton seed cake and soyabean meal as a source of protein in different CFM.

Table (2): Ingredients of concentrate feed mixtures containing different levels of guar korma in experimental rations.

\begin{tabular}{|l|c|c|c|c|c|c|}
\hline \multirow{2}{*}{ Items } & \multicolumn{7}{|c|}{ *CFM of experimental rations } \\
& \multicolumn{7}{|c|}{ B } & C & D & E & F \\
\cline { 2 - 7 } & A & B & & & & \\
Ingredients (\%): & - & 3.3 & 6.7 & 10.0 & 13.3 & 16.7 \\
Guar korma** & 32 & 28 & 28 & 29 & 28 & 26 \\
Yellow corn & 18 & 18.7 & 19.3 & 20 & 28.7 & 30.3 \\
Rice bran & 17 & 15 & 14 & 13 & 5 & - \\
Wheat bran Seed Cake & 15 & 21 & 21 & 20 & 17 & 15 \\
Soybean Meal (44\%) & 10 & 6 & 3 & - & - & - \\
Molasses & 5 & 5 & 5 & 5 & 5 & 9 \\
Limestone & 2 & 2 & 2 & 2 & 2 & 2 \\
Salt & 1 & 1 & 1 & 1 & 1 & 1 \\
\hline
\end{tabular}

* CFM: Concentrate feed mixture.

** Guar korma is used as a source of protein with rate of $0,10,20,30,40$ and $50 \%$ from protein of concentrate feed mixture (CFM) of experimental rations.

All CFM containing different levels of guar korma had almost equal $\mathrm{DM}, \mathrm{OM}$ and CP contents. Increasing guar korma percentages in CFM tended to increase EE and Ash contents and decreased CF and NFE contents (Table 3).

Table (3):Chemical composition of concentrate feed mixtures containing different levels of Guar korma, berseem hay and wheat straw.

\begin{tabular}{|c|c|c|c|c|c|c|c|}
\hline \multirow{2}{*}{ Items } & \multirow{2}{*}{$\begin{array}{c}\text { DM } \\
\text { (\%) }\end{array}$} & \multicolumn{3}{|c|}{$\begin{array}{c}\text { Chemical Composition } \\
\text { On DM bases (\%) }\end{array}$} & $\begin{array}{c}\text { OM } \\
\text { (\%) }\end{array}$ \\
\cline { 3 - 7 } & & CP & EE & CF & NFE & Ash & \\
\hline Berseem hay (BH) & 90.20 & 15.80 & 3.02 & 24.65 & 47.13 & 9.40 & 90.60 \\
Wheat straw (WS) & 91.38 & 3.17 & 1.86 & 43.26 & 40.89 & 10.82 & 89.18 \\
Guar Korma (GK) & 89.82 & 48.01 & 3.10 & 14.08 & 27.61 & 7.20 & 92.80 \\
& & & & & & & \\
* CFM containing 0\% GK & 88.50 & 16.04 & 4.69 & 9.28 & 61.74 & 8.25 & 91.75 \\
CFM containing 3.3\% GK & 88.54 & 16.02 & 4.88 & 9.65 & 60.95 & 8.50 & 91.50 \\
CFM containing 6.7\% GK & 88.59 & 16.15 & 5.00 & 9.77 & 60.52 & 8.56 & 91.44 \\
CFM containing 10.0\% GK & 88.63 & 16.17 & 5.14 & 9.80 & 60.31 & 8.58 & 91.42 \\
CFM containing 13.3\% GK & 88.68 & 16.25 & 6.15 & 9.03 & 59.34 & 9.23 & 90.77 \\
CFM containing 16.7\% GK & 88.72 & 16.47 & 6.25 & 8.26 & 59.37 & 9.65 & 90.35 \\
\hline
\end{tabular}

* CFM: Six Concentrate feed mixtures of different experimental rations. 
Data presented in Table (3) showed that the incorporation of guar korma meal at the rate of $0,3.3,6.7,10.0,13.3$ and $16.7 \%$ to cover $0,10,20,30,40$ and $50 \%$ protein of CFM, respectively. However, most of nutrients of different CFM were almost equal.

In addition, chemical composition of berseem hay and wheat straw werewithin the same range which reported by Etman et al., (2014) and ElNahas (2010).

\section{Effect of feeding guar korma on digestibility and nutritive values:}

Data presented in Table (4) showed that the average daily feed intake in terms of concentrate feed mixture, berseem hay and wheat straw increased with increasing guar korma percentages in experimental rations.

Average total DM intake were 10.801, 11.032, 11.141, 11.400, 11.438 and $11.704 \mathrm{~kg} / \mathrm{head}$ for rations $A, B, C, D, E$ and $F$, respectively. It could be noticed that increasing guar korma from zero (ration $\mathrm{A}$ ) to $16.7 \%$ (ration $\mathrm{F}$ ) tended to increase total DM intake by $8.33 \%$. So, increasing guar korma percentage in experimental rations increased CFM, berseem hay and wheat straw intakes as shown in Table 4). Kholif (1999), Saleh pour et al., (2012) and Turki et al., (2011) were agreement with our results.

The calculated chemical composition of experimental rations showed that the DM\% ranged between 89.13 to $89.28 \%$, CP\% ranged between 14.69 to $15.01 \%$ while CF ranged between 15.04 to $16.12 \%$ (Table 4 ). All of the experimental rations were iso-nitrogenous and iso-energetic. The digestibility coefficients of all nutrients for experimental rations are shown in Table (4). The data showed that the digestibility coefficients of DM was significantly $(p<0.05)$ higher for ration $F(85.79 \%)$, while differences in DM digestibility among other rations were not significant. Also, high significant difference was observed for DM digestibility with ration $\mathrm{F}$ being $93.78 \%$. Differences in $\mathrm{OM}$ digestibility between both rations $D$ and $E$ or between $E$ and $F$ were not statistically significant. Also, differences in $\mathrm{OM}$ digestibility among the $1^{\text {st }}$ three rations ( $A, B$ and $C$ ) were not statistically significant. On the other hand, increasing guar korma percentage to $16.7 \%$ (ration $F$ ) significantly $(p<0.05)$ increased in CP digestibility, being $73.20 \%$ versus $65.25,65.97,67.18,67.44$ and $69.43 \%$ with rations $A, B, C, D$ and $E$, respectively. At the time, differences in $C P$ digestibility between rations $A$ and $B$ or among $C, D$ and $E$ rations were not statistically significant $(\mathrm{P}<0.05$; Table 4$)$. However, increasing guar korma in experimental rations to cover $50 \%$ of CP of CFM increased significantly $(P<0.05) \quad C P$ digestibility by $12.18 \%$. Also, digestibility of $E E$ significantly $(P<0.05)$ increased with increasing guar korma percentages, but differences in $E E$ digestibility between rations $E$ and $F$ or among $B, C$ and $D$ rations were not statistically significant. Similar trend was observed for CF digestibility, which increased with increasing guar korma percentages. The CF digestibility recorded $58.81,60.17,61.21,62.23,65.34$ and $65.59 \%$ for rations A,B,C,D,E and $F$, respectively. Differences in NFE digestibilities among different experimental rations were not significant (Table 4). 
J.Animal and Poultry Prod., Mansoura Univ., Vol. 5 (12), December, 2014 
The nutritive values of different experimental rations expressed as TDN (\%), DCP (\%) and DE (kcal/kg DM) are shown in Table (4). The TDN were $68.02,68.87,69.06,69.27,70.78$ and $70.82 \%$ for rations $A, B, C, D, E$ and $F$, respectively. Corresponding values of DCP were 9.60, 9.84, 9.94, 9.98, 10.32 and $10.99 \%$, respectively. The DE values were $3.00,3.04,3.04,3.05,3.12$ and $3.12(\mathrm{kcal} / \mathrm{kg} \mathrm{DM})$ for the respective rations. The data revealed that increasing guar korma percentage to cover 50\% CP of CFM for experimental ration (ration $\mathrm{F}$ ) significantly $(\mathrm{P}<0.05)$ increased $\operatorname{TDN}(\%), \mathrm{DCP}(\%)$ and $\mathrm{DE}$ (kcal/kg DM), while differences with increasing guar korma from $40 \%$ to $50 \%$ were not significant $(P<0.05)$.

Generally, guar korma improved and increased digestibility coefficients for most of nutrients and nutritive values especially up to the rate of $50 \%$ as a source of protein of CFM. These results were agreement with those reported by Farkhanda et al.,(2006) and Saleh pour et al., (2012). In addition, Shwerab et al., (2010)showed higher digestibility coefficients and nutritive value with increasing DDGS in sheep rations. The same results were obtained with Etman et al., (2011). They found that using DDGS as a source of protein in rations formulation of buffalo calves increased digestibility coefficients of all nutrients and feeding values.

\section{Effect of feeding guar korma on feed intakes:}

Data illustrated in Table (5) showed average daily feed intakes per head, $100 \mathrm{~kg} \mathrm{LBW}$ and $W^{0.75}$. Results revealed that average daily $\mathrm{kg}$ DM intake/head increased with increasing guar korma in the experimental rations. Increasing in DM intake with increasing guar korma up to $50 \%$ in CFM up to $8.36 \%$. The increase in $\mathrm{kg}$ TDN intake/head was $13.13 \%$ versus $24.10 \%$ for $\mathrm{kg} \mathrm{DCP/head}$

Table (5): Averages daily feed unite intake for different experimental rations.

\begin{tabular}{|l|c|c|c|c|c|c|c|}
\hline \multirow{2}{*}{ Items } & \multicolumn{7}{|c|}{ Experimental rations } \\
\cline { 2 - 7 } & A & B & C & D & E & F \\
\hline AV. Daily feed intake expressed as: & 10.801 & 11.032 & 11.141 & 11.400 & 11.438 & 11.704 \\
\hline Kg DM/head & 7.347 & 7.598 & 7.694 & 7.897 & 8.096 & 8.289 \\
Kg TDN/head & 1.037 & 1.086 & 1.107 & 1.138 & 1.180 & 1.286 \\
Kg DCP/head & & & & & & \\
& 3.460 & 3.470 & 3.475 & 3.484 & 3.485 & 3.500 \\
Kg DM/100Kg LBW & 2.374 & 2.411 & 2.417 & 2.425 & 2.477 & 2.479 \\
Kg TDN/100Kg LBW & 0.336 & 0.345 & 0.348 & 0.349 & 0.361 & 0.385 \\
Kg DCP/ 100Kg LBW & & & & & & \\
& 2.548 & 2.600 & 2.616 & 2.671 & 2.679 & 2.737 \\
Kg DM/kg W & 1.748 & 1.806 & 1.820 & 1.859 & 1.904 & 1.939 \\
Kg TDN/ kg W & 0.75 & 0.247 & 0.258 & 0.262 & 0.268 & 0.277 & 0.301 \\
Kg DCP/ kg W
\end{tabular}

It could be noticed that, average $\mathrm{kg}$ DM intake/100kg LBW ranged between 3.460 to $3.500 \mathrm{~kg}$, while $\mathrm{kg}$ TDN intake/100kg LBW ranged between 2.374 to $2.479 \mathrm{~kg}$, while it ranged between 0.336 to $0.385 \mathrm{~kg}$ as $\mathrm{kg}$ $\mathrm{DCP} / 100 \mathrm{~kg}$ LBW. When average daily feed unite calculated as $\mathrm{kg}$ intake/kg $\mathrm{W}^{0.75}$, it was found that increasing guar korma at $50 \%$ experimental ration increased feed intake by $7.42,10.93$ and $21.86 \%$ as $\mathrm{kg}$ DM, TDN and $\mathrm{DCP} / \mathrm{kg} \mathrm{W}^{0.75}$, respectively (Table 5 ). 
Data presented in Table (5) showed that the average daily feed unite intakes increased with increasing guar korma percentages in CFM owing due to its high palatability and higher both digestibility and feeding values of guar korma. Such results were agreement with those reported by Etman et al., 2011 and 2014; Turki et al., 2011; Shwerab et al., 2010 and Sehgal and Makker, 1994.

\section{Effect of feeding guar korma on blood parameters:}

Data presented in Table (6) revealed that the serum total protein ranged between 6.34 to $7.12 \mathrm{gm} / 100 \mathrm{ml}$, showing significant differences among different treatments. Concentrations of serum albumin ranged between 3.82 to $4.38 \mathrm{gm} / 100 \mathrm{ml}$ with also significant $(P<0.05)$ differences among different treatments, while concentrations of serum globulin ranged between 2.52 to $2.74 \mathrm{gm} / 100 \mathrm{ml}$ showing no significant differences among treatments. It could be noticed that albumin and globulin concentrations increased with increasing guar korma levels, while albumin/globulin ratio was almost similar in all treatments, as shown in Table (6).

The ratio between albumin and globulin (A/G ratio) were reflected to the values of both. The results also revealed that the Aspartate Amino Transferase (AST) concentrations increased with increasing guar korma level, showing significantly $(P<0.05)$ higher concentration with ration $F(45.35$ IU/L). The same significant trend was observed with Alanin Amino Transferas (ALT) with ration $\mathrm{F}$, recording $25.15 \mathrm{IU} / \mathrm{L}$. Increasing guar korma level up to $30 \%$ as a source of protein of CFM tended to increase in both AST and ALT concentrations with no significant differences. However, increasing guar korma level up to 40 or $50 \%$ of CFM resulted in significantly $(P<0.05)$ higher AST and ALT concentrations, as shown in Table (6). On the other hand, the kidney function was measured as creatinine and blood urea-N (BUN) activities. Creatinine is a natural product of muscle breakdown that occurs at a low level in the body. Both BUN and creatinine are filtered by kidney and excreted in the urine. For this reason, BUN and creatinine are used together to measure kidney function. It could be noticed that the creatinine concentration ranged between 1.12 to $1.20 \mathrm{mg} / \mathrm{d}$, while blood urea- $\mathrm{N}$ concentration ranged between 17.74 to $20.94 \mathrm{mg} / 100 \mathrm{ml}$. Both creatinine and blood urea- $\mathrm{N}$ concentrations decreased with increasing guar korma levels. There differences were not statistically significant. Also, the ratio between BUN and creatinine ranged between 15.84 to 17.76 and these rations were within the normal range .

Generally, all values and concentrations of different items obtained in Table (6) were within the normal range. This mean that all experimental animals were in a good health and guar korma were better material as a source of protein for ruminant feedstuffs. The results obtained in Table (6) were in agreement with those reported by Ojha et al.,(2013), Saleh pour et al., (2012), Etman et al., (2014) and Shwerab et al., (2010). 
Etman, K.E. et. al. 


\section{Effect of feeding guar korma on daily gain and feed efficiency:}

Data presented in Table (7) revealed that averages total live body weight gains were 272.2, 278.3, 284.9, 292.3, 299.2 and $309.8 \mathrm{~kg}$ for animals fed rations $A, B, C, D, E$ and $F$, respectively. Corresponding, values of daily gains were $1.296,1.325,1.357,1.392,1.425$ and $1.475 \mathrm{~kg} /$ day, respectively. It could be noticed that both total and daily gains increased with increasing guar korma levels in experimental rations. The improvements in daily gains were $2.24,4.71,7.41,9.95$ and $13.81 \%$ with animals fed rations $B, C, D, E$ and $F$, respectively. Increasing in both total body weight and daily gains with increasing guar korma levels might be attributed to increase TDN and DCP intake of experimental rations. Also, might be due to the higher digestibility and nutritive values of guar korma. Generally, experimental rations containing guar korma had significantly $(P<0.05)$ higher daily gains. Moreover, ration containing $16.7 \%$ guar korma (ration $\mathrm{F}$ ) showed the highest total and daily gain $(309.8$ and $1.475 \mathrm{~kg}$ ) with the best improvements $(13.81 \%)$. It could be noticed that, increasing total and daily gain with increasing guar korma levels might be due to higher digestibility and nutritive values of the rations containing guar korma and also higher feed intake of those rations. The feed utilization efficiency values expressed as the amounts of DM, TDN or DCP consumed per $\mathrm{kg}$ gain, are shown in Table (7). It could be noticed that animals fed ration $\mathrm{F}$ containing the highest level of guar korma had the highest feed utilization efficiency expressed as $\mathrm{kg}$ DM and TDN consumed per kg gains, being 7.935 and $5.620 \mathrm{~kg}$, respectively. Moreover, animals fed ration $F$ had the highest $(P<0.05)$ feed utilization efficiency, while the feed utilization of DCP showed significantly $(P<0.05)$ the lowest efficiency. The data revealed that increasing guar korma level increased feed utilization efficiency as $\mathrm{kg} \mathrm{DM} / \mathrm{kg}$ gain and decreased feed utilization efficiency as $\mathrm{kg}$ DCP $/ \mathrm{kg}$ gain. However, increasing guar korma level up to $40 \%$ of CFM had no effect on feed utilization efficiency as $\mathrm{kg}$ TDN/kg gain, while increasing level up to $50 \%$ of CFM (ration F) gave the highest feed utilization efficiency (5.620), as shown in Table (7). The results were in agreement with those reported by Etman et al., (2014), Turki et al., (2011), Ahmed et al., (2000), Sehgal and Makker (1994). In addition, Ojha et al., (2013) reported that inclusion of guar meal at $10 \%$ level in concentrate feed mixture of growing crossbred calves significantly improved average daily gain.

Feed cost and economical efficiency:

Data presented in Table (8) showed that the feed cost $/ \mathrm{kg}$ weight gain decreased with increasing guar korma levels, being 18.870, 18.227, 17.429,16.650, 15.822 and 15.249 LE with rations $A, B, C, D, E$ and $F$, respectively. Corresponding values of revenue expressed as LE/head /day were $4.057,4.977,6.203,7.447,8.803$ and 9.958 , respectively. The results showed that the animals fed ration $\mathrm{F}$ containing the highest level of guar korma $(16.7 \%)$ had the highest revenue, being 0.443 LE as a gross margin above feed cost. It could be noticed that the profit percentage recorded $16.59,20.70,26.23,32.13,39.04$ and $44.27 \%$ with rations $A, B, C, D, E$ and $F$, respectively, showing the animals fed ration containing the highest guar korma level (ration F) had the highest profit. 
Etman, K.E. et. al. 
J.Animal and Poultry Prod., Mansoura Univ., Vol. 5 (12), December, 2014 
Almost similar trend, was recorded with increasing guar korma level in experimental rations increased economical efficiency, being 1.166, 1.207, $1.262,1.321,1.390$ and 1.443 with rations $A, B, C, D, E$ and $F$, respectively. Also, there were improvements in economical efficiency with increasing guar korma level in experimental rations, being 3.52, 8.23, 13.29, 19.21 and $23.76 \%$ with rations $B, C, D, E$ and $F$, respectively.

From the previous results, it may be shown that the animals fed rations containing the highest level of guar korma (16.7\%) which represent $50 \%$ as a source of protein of CFM appeared to have the lowest feed cost $/ \mathrm{kg}$ gain with the highest revenue, profit and economical efficiency. The results were agreement with those reported by Turki et al., (2011), Saleh pour et al.(2012), TarunaKhanna et al., (2010) and Etman et al., (2011 and 2014)

\section{CONCLUSION}

Guar korma meal could be used as a source of protein to partially or totally replace cotton seed cake and soybean meal in concentrate feed mixture of growing buffalo calves rations. Moreover, guar korma meal could be used at the rate of $50 \%$ in CFM instead of both cotton seed cake and soybean meal in ration formulation of buffalo calves. Increasing guar korma at the rate of $50 \%$ in CFM in buffalo calves rations significantly increased nutrients digestibility, nutritive values as TDN and DCP, daily LBW gain, improved feed utilization efficiency, decreased feed cost $/ \mathrm{kg}$ weight gain and increased both the revenue and economical efficiency. Moreover, using guar korma in ration formulation of buffalo calves had not affected liver and kidney functions. However, further work is needed to determine the optimum level of guar korma to be used in rations of growing buffalo calves, to achieve maximum performance.

\section{REFERENCES}

A.O.A.C. (2000). Association of Official Analytical chemists. Official Methods of Analysis, Washington, D.C., USA.

Abou-Raya, A.K. (1967). Animal and Poultry Nutrition (In-Arabic), Al-Anglo Press, Cairo, Egypt.

Ahmed, M, M. M.;F.M. El-Hag, and M.M. Awouda, (2000). The use of guar meal in diet of sheep. J. Animal and feed Science, 9(1): 91-98.

Altrafine Gum (2011). Animal feed additives (Guar korma), Gujarat, India.

Cornell, A. G.; C.J. Badawill and M.M.David, (1949). Determination of serum proteins by means of the buriet reaction. J. Biochem., 177:551.

Church,D.C.(1984). Livestock feed and feeding. $2^{\text {nd }}$ ed.,O\& B Books, Inc., 1215 NW K Line Place, Corvallis, Oregon,US.

Drupt, E. (1974). Colorimetric determination of albumin, Journal of Biocology, 9: 777.

Duncan, D.B. (1955). The multiple range and $F$ test. Biometrics, 11: 1-45.

El-Nahas, H.M. (2010). Effect of zinc sulfate and/or manganese sulfate supplementation on Friesian calves performance. J. animal and Poultry Prod., Mansura Univ., Vol. 7 (11): 575-588. 
Etman, K. E. I.; El-Monayer, T. I.; Sayed, S. K.; El-Sayed, F.A. and Mona, E. Farag (2014). Some studies on using different levels of dried distillers grains with solubles (DDGS) on animal performance. 1- Effect of feeding different levels of DDGS as a source of energy on sheep performance. J. Animal and Poultry Prod., Mansoura University, Vol. $5(2): 27-41$.

Etman, K. E. I.; El-Monayer, T. I.; Zeid, A. M. M.; Ebtehag, I. M. Abou-Elenin and Sayed, S. K. (2011). Utilization of new nutritional resources in ruminant feeding. 2) Effect of using dried distillers grains with soluble (DDGS) as protein source in rations for fattening buffalo calves. J. Animal and Poultry Prod., Mansoura University, Vol. 2(6): 201-215.

Farkhanda, A. ;S.Muhammad, ;S.Khurran, and N.Uzma, (2006). Estimation of apparent digestibility coefficient of guar, Canola and meat meal for Labeorohita. International J. Agriculture and Biology, 7(5): 816-819.

Fawcett, J.K. and J.E. Scott (1960). Colorimeteric determination of Urea. An. J. Clin. Path., B, 156.

Kholif, A. M. (1999). Yield and composition of milk and some blood parameters of goats as affected by including guar gums as aprotein source in the ration. Egyptian J. Dairy Science, 27(1): 27-36.

Ojha, B. K.; Singh; Singh, P.; Vema, A. K.; Chaturvedi, V. B. and Ajit Kumar (2013).Effect of feeding deoiledmahua seed cake and guar meal on blood biochemicals, immune response and urinary purine derivatives in crossbred calves. Animal Nutrition and Feed Technology, 13(1):69-78.

Pond,W.G.; D.C. Church and K.R.Pond (1995). Basic Animal Nutrition and Feeding. $4^{\text {th }}$ ed., New Yourk, Chichester, Brisbonce, Toronto and Singapore.

Reitman, S. and S. Frankel (1957). A colorimetric method for determination of serum glutamic oxaloacetic and glutamic pyruvic transminases. Amer. J. Clin. Path., 28; 56-63.

Saleh pour, M.;K. Qazvinian and V.A.P. Cadavez (2012). Effect of feeding different levels of guar meal on performance and blood metabolities in Holstein lactating cows. Scientific papers, Series D. Animal Science, 55:73-77.

SAS (2000). Statistical Analysis System/User's Guide Static's Ver. 6-06.4 th $^{\text {th }}$ Ed. SAS Institute Inc., Cary, NC., U.S.A.

Sehgal, J. P. and G.S. Makker (1994). Protein evaluation in ruminants invitro, in-sacco, in-vivo, protein degradability and microbial efficiency of different protein supplements in growing buffalo calves. Animal Feed Science and Technology, 45(2): 149-165.

Shwerab, A. M.; M. S. Khalel; A. A. Hassan; Amany, A. Khayyal and M. H. Yacout (2010). Optimizing the use of corn dried distillers grains with soluble in sheep production. Egyptian J. Nutrition and Feeds, 13(3):415-431.

Srivastava, S.; Sh. Anees and R. Ramani (2011). Science Reporter, Indian Institute of Natural Resins and Gum (IINRG), November, 2011.

TarunaKhanna; R.Katoch and T.Shama (2010). Comparative study of nutrient utilization in conventional and complete feeding systems in sheep. Veterinary Practitioner, 11(1):50-52.

Techical Bulletin, (2001). Central Lab for Food and Feed,NO.1,2001,Egypt.

Turki, I. Y.; O.A.Elkadier,M. El-Amin and A.A.Hassabo (2011). Effect of different dietary protein source on performance of western Baggara cattle. Veterinary Science Research, 2(1):8-12.

Young, D.S. (1990). Effect of drug on clinical laboratory tests. $3^{\text {rd }}$ Ed. AACC Press, Washington, D.C., USA. 


\section{إستخدام مصادر بروتينية جديدة في تغذية المجترات \\ اـ تأثير إستخذام نسب مختلفة من جوار الكورمـا كمصدر بروتينى على فلى الأداء الاتتاجى للجاموس

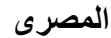

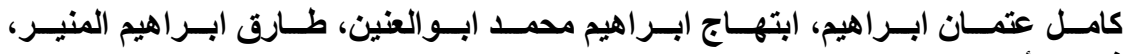 فاروق أمين السيد انيد \\ معه بحوث الاتتاج الحيوانى- مركز البحوث الزراعية - وزارة الزراعة-ج.م.ع.}

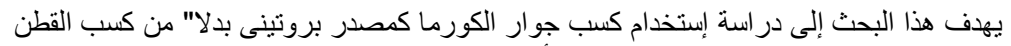

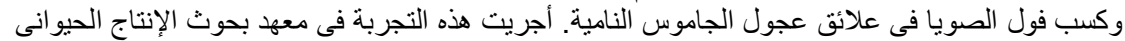
التابع لمركز البحوث الزر عاعية بجمهورية مصر العرب العربية.

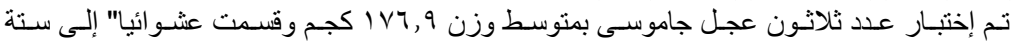

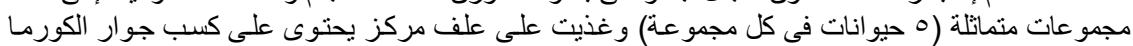

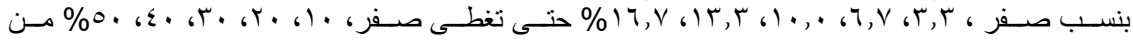

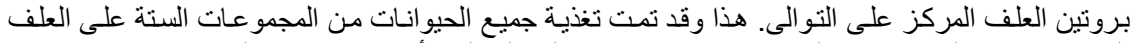

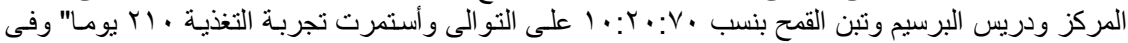

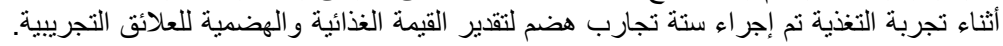

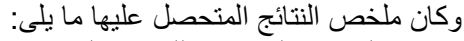

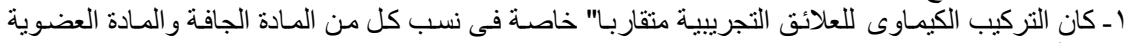

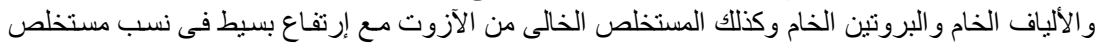

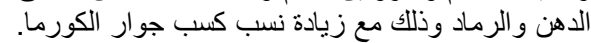

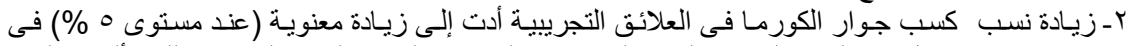

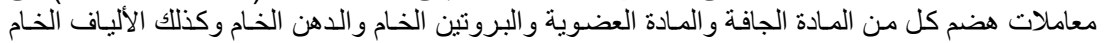

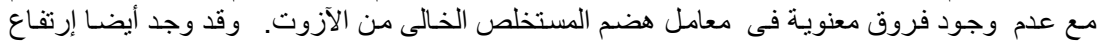

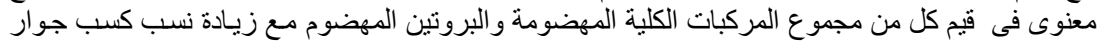

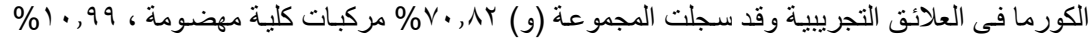
بروتين مهضوم.

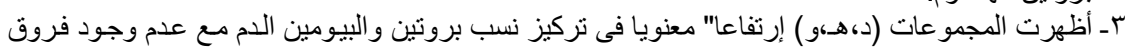

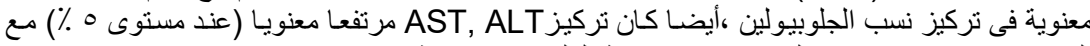

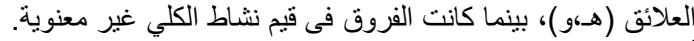

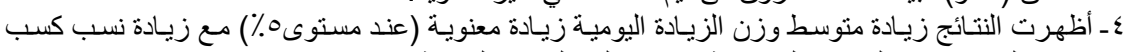

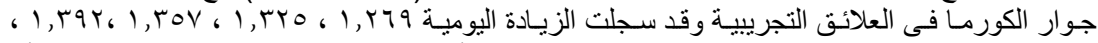

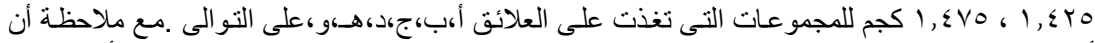

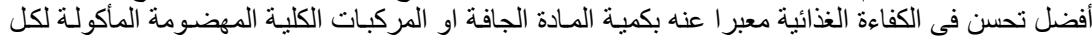

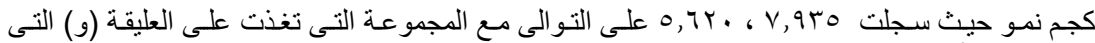

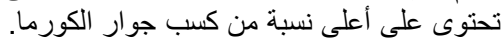

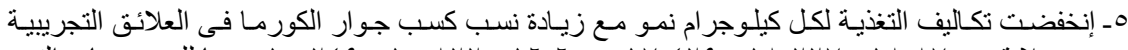

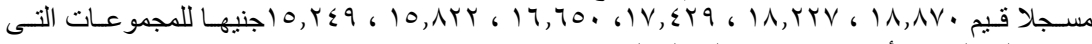

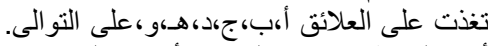

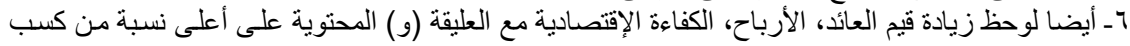

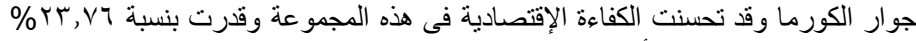

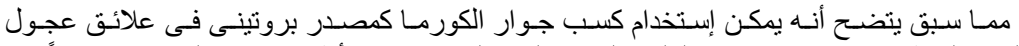

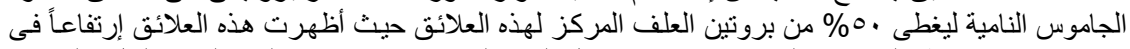

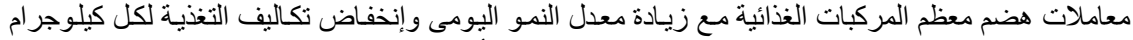

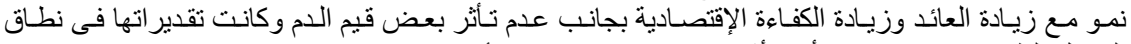

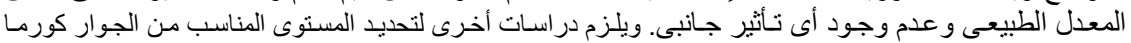

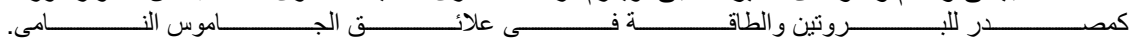


J.Animal and Poultry Prod., Mansoura Univ., Vol. 5 (12): 619 - 634, 2014 
Etman, K.E. et. al.

Table (4):Average daily feed intake, calculate composition, digestibility coefficients and nutritive values of different experimental rations.

\begin{tabular}{|c|c|c|c|c|c|c|c|}
\hline \multirow{2}{*}{ Items } & \multicolumn{6}{|c|}{ Experimental rations } & \multirow{2}{*}{$\begin{array}{l}\text { Significant } \\
\text { levels }\end{array}$} \\
\hline & A & B & $\mathrm{C}$ & $\mathrm{D}$ & $E$ & $\mathrm{~F}$ & \\
\hline \multicolumn{7}{|c|}{ AV. Daily feed intake (Kg DM/Head): } & \\
\hline Concentrate feed mixture & 7.561 & 7.722 & 7.799 & 7.980 & 8.007 & 8.193 & \\
\hline Berseem hay & 2.160 & 2.207 & 2.228 & 2.280 & 2.287 & 2.341 & \\
\hline Wheat straw & 1.080 & 1.103 & 1.114 & 1.140 & 1.144 & 1.170 & \\
\hline Total DM intake & 10.801 & 11.032 & 11.141 & 11.400 & 11.438 & 11.704 & \\
\hline \multicolumn{8}{|c|}{ Calculated composition of experimental rations: } \\
\hline DM & 89.13 & 89.16 & 89.19 & 89.22 & 89.26 & 89.28 & \\
\hline OM & 91.26 & 91.09 & 91.05 & 91.05 & 90.58 & 90.28 & \\
\hline $\mathrm{CP}$ & 14.71 & 14.69 & 14.79 & 14.80 & 14.86 & 15.01 & \\
\hline $\mathrm{EE}$ & 4.07 & 4.21 & 4.29 & 4.39 & 5.10 & 5.17 & \\
\hline CF & 15.76 & 16.02 & 16.10 & 16.12 & 15.58 & 15.04 & \\
\hline NFE & 56.72 & 56.17 & 55.87 & 55.72 & 55.04 & 55.06 & \\
\hline Ash & 8.74 & 8.91 & 8.95 & 8.97 & 9.42 & 9.72 & \\
\hline \multicolumn{8}{|c|}{ Digestibility Coefficients of experimental rations: } \\
\hline DM & $83.72^{\mathrm{b}}$ & $84.80^{\mathrm{b}}$ & $84.85^{\mathrm{b}}$ & $84.95^{\mathrm{b}}$ & $85.05^{\mathrm{ab}}$ & $85.79^{a}$ & $(P<0.05)$ \\
\hline OM & $89.93^{c}$ & $91.30^{c}$ & $91.34^{\mathrm{c}}$ & $92.32^{\mathrm{b}}$ & $92.59^{\mathrm{ab}}$ & $93.78^{a}$ & $(P<0.05)$ \\
\hline $\mathrm{CP}$ & $65.25^{c}$ & $65.97^{c}$ & $67.18^{\mathrm{b}}$ & $67.44^{\mathrm{b}}$ & $69.43^{b}$ & $73.20^{a}$ & $(P<0.05)$ \\
\hline $\mathrm{EE}$ & $67.01^{\mathrm{c}}$ & $68.79^{b}$ & $68.57^{\mathrm{b}}$ & $68.19^{b}$ & $70.80^{\mathrm{a}}$ & $70.78^{\mathrm{a}}$ & $(P<0.05)$ \\
\hline $\mathrm{CF}$ & $58.81^{c}$ & $60.17^{\mathrm{b}}$ & $61.21^{\mathrm{b}}$ & $62.23^{b}$ & $65.34^{a}$ & $65.59^{a}$ & $(P<0.05)$ \\
\hline NFE & 75.83 & 76.30 & 76.34 & 76.32 & 76.59 & 75.78 & NS \\
\hline \multicolumn{8}{|l|}{ Nutritive values: } \\
\hline TDN (\%) & $68.02^{c}$ & $68.87^{\mathrm{bc}}$ & $69.06^{\mathrm{b}}$ & $69.27^{\mathrm{b}}$ & $70.78^{a}$ & $70.82^{a}$ & $(P<0.05)$ \\
\hline DCP $(\%)$ & $9.60^{\mathrm{b}}$ & $9.84^{\mathrm{b}}$ & $9.94^{\mathrm{b}}$ & $9.98^{\mathrm{b}}$ & $10.32^{\mathrm{a}}$ & $10.99^{a}$ & $(P<0.05)$ \\
\hline * DE (Mcal/Kg DM) & $3.00^{\mathrm{b}}$ & $3.04^{\mathrm{b}}$ & $3.04^{\mathrm{b}}$ & $3.05^{\mathrm{b}}$ & $3.12^{\mathrm{a}}$ & $3.12^{\mathrm{a}}$ & $(\mathrm{P}<0.05)$ \\
\hline
\end{tabular}

a, $b$ and $c$ : Means in the same raw with different superscripts are significant $(P<0.05)$ differed.

* DE was calculated according to Pond et al., (1995). 
J.Animal and Poultry Prod., Mansoura Univ., Vol. 5 (12), December, 2014 
Etman, K.E. et. al.

Table (6): Some blood parameters of animals fed different experimental rations.

\begin{tabular}{|c|c|c|c|c|c|c|c|}
\hline \multirow{2}{*}{ Items } & \multicolumn{6}{|c|}{ Experimental rations } & \multirow{2}{*}{$\begin{array}{l}\text { Significant } \\
\text { levels }\end{array}$} \\
\hline & $\mathbf{A}$ & B & $\mathrm{C}$ & D & $E$ & $F$ & \\
\hline Serum protein $(\mathrm{gm} / 100 \mathrm{ml})$ & & & & & & & \\
\hline Total protein & $6.34^{b}$ & $6.55^{\mathrm{b}}$ & $6.65^{\mathrm{b}}$ & $6.91^{a}$ & $6.98^{a}$ & $7.12^{a}$ & $(P<0.05)$ \\
\hline Albumin (A) & $3.82^{b}$ & $3.94^{b}$ & $4.01^{b}$ & $4.26^{a}$ & $4.30^{a}$ & $4.38^{a}$ & $(P<0.05)$ \\
\hline Globulin (G) & 2.52 & 2.61 & 2.64 & 2.65 & 2.68 & 2.74 & NS \\
\hline $\begin{array}{l}\text { A/G ratio } \\
\text { Liver functions (IU/L): }\end{array}$ & 1.52 & 1.51 & 1.52 & 1.61 & 1.60 & 1.60 & \\
\hline GOT (AST) & $40.21^{b}$ & $40.86^{b}$ & $41.24^{b}$ & $41.80^{b}$ & $45.10^{a}$ & $45.35^{a}$ & $(P<0.05)$ \\
\hline $\begin{array}{l}\text { GPT (ALT) } \\
\text { Kidney functions: }\end{array}$ & $20.42^{\mathrm{b}}$ & $20.51^{\mathrm{b}}$ & $20.68^{b}$ & $21.25^{b}$ & $24.64^{a}$ & $25.15^{\mathrm{a}}$ & $(P<0.05)$ \\
\hline Creatinine $(\mathrm{mg} / \mathrm{dl})$ & 1.20 & 1.18 & 1.17 & 1.17 & 1.14 & 1.12 & NS \\
\hline Urea-N (mg/100ml) & 20.94 & 20.16 & 19.61 & 19.60 & 18.92 & 17.74 & NS \\
\hline BUN/Creatinine & 17.45 & 17.08 & 16.76 & 16.75 & 16.60 & 15.84 & \\
\hline
\end{tabular}

$a$ and $b$ : Means in the same raw with different superscripts are significant $(P<0.05)$ differed.

NS: Not significant 
Table (7): Averages daily, total gains and feed utilization efficiency of animals fed different experimental rations.

\begin{tabular}{|c|c|c|c|c|c|c|c|}
\hline \multirow{2}{*}{ Items } & \multicolumn{6}{|c|}{ Experimental rations $^{*}$} & \multirow{2}{*}{$\begin{array}{c}\text { Significant } \\
\text { levels }\end{array}$} \\
\hline & A & B & C & D & $\mathbf{E}$ & $\mathbf{F}$ & \\
\hline No. of animals & 5 & 5 & 5 & 5 & 5 & 5 & \\
\hline Experimental period, day & 210 & 210 & 210 & 210 & 210 & 210 & \\
\hline Av. initial LBW, Kg & 172.5 & 176.7 & 175.8 & 179.5 & 177.2 & 179.5 & \\
\hline Av. final LBW, $\mathrm{Kg}$ & 444.7 & 455.0 & 460.7 & 471.8 & 476.4 & 489.3 & \\
\hline Av. total LBW gain, $\mathrm{Kg}$ & 272.2 & 278.3 & 284.9 & 292.3 & 299.2 & 309.8 & \\
\hline Av. daily LBW gain, $\mathrm{Kg}$ & $1.296^{c}$ & $1.325^{b c}$ & $1.357^{b}$ & $1.392^{\mathrm{b}}$ & $1.425^{\mathrm{ab}}$ & $1.475^{\mathrm{a}}$ & $(P<0.05)$ \\
\hline Improvement, (\%) & - & 2.24 & 4.71 & 7.41 & 9.95 & 13.81 & \\
\hline \multicolumn{8}{|l|}{ AV. Daily feed intake: } \\
\hline Kg DM/head & 10.801 & 11.032 & 11.141 & 11.400 & 11.438 & 11.704 & \\
\hline $\mathrm{Kg}$ TDN/head & 7.347 & 7.598 & 7.694 & 7.897 & 8.096 & 8.289 & \\
\hline $\mathrm{Kg} \mathrm{DCP/head}$ & 1.037 & 1.086 & 1.107 & 1.138 & 1.180 & 1.286 & \\
\hline \multicolumn{8}{|l|}{ Feed utilization efficiency: } \\
\hline $\mathrm{Kg} \mathrm{DM} / \mathrm{Kg}$ gain & $8.334^{a}$ & $8.326^{a}$ & $8.210^{\mathrm{b}}$ & $8.190^{\mathrm{b}}$ & $8.027^{c}$ & $7.935^{c}$ & $(P<0.05)$ \\
\hline $\mathrm{Kg}$ TDN/Kg gain & $5.669^{a}$ & $5.734^{a}$ & $5.670^{\mathrm{b}}$ & $5.673^{b}$ & $5.681^{c}$ & $5.620^{c}$ & $(P<0.05)$ \\
\hline $\mathrm{Kg} \mathrm{DCP/} \mathrm{Kg} \mathrm{gain}$ & $0.800^{c}$ & $0.820^{\mathrm{b}}$ & $0.816^{b}$ & $0.818^{\mathrm{b}}$ & $0.828^{b}$ & $0.872^{\mathrm{a}}$ & $(P<0.05)$ \\
\hline
\end{tabular}

a, $b$ and $c:$ Means in the same raw with different superscripts are significant $(P<0.05)$ differed.

concentrate feed mixture (CFM) of experimental rations containing guar korma with rate of $0,10,20,30,40$ and $50 \%$ as a source of protein in $A, B, C, D, E$ and $F$ rations, respectively. 
Table (8): Averages daily feed intake as fed, daily gain, feed cost and economical efficiency of animals fed different experimental rations.

\begin{tabular}{|c|c|c|c|c|c|c|}
\hline \multirow{2}{*}{ Items } & \multicolumn{6}{|c|}{ Experimental rations } \\
\hline & A & B & $\mathbf{C}$ & D & $\mathbf{E}$ & $\mathbf{F}$ \\
\hline \multicolumn{7}{|l|}{ AV. daily feed intake, as fed (Kg): } \\
\hline Concentrate feed mixture & 8.544 & 8.721 & 8.803 & 9.004 & 9.029 & 9.235 \\
\hline Berseem hay & 2.395 & 2.447 & 2.470 & 2.528 & 2.535 & 2.595 \\
\hline Wheat straw & 1.182 & 1.207 & 1.219 & 1.248 & 1.252 & 1.280 \\
\hline Av. daily L.B.W. gains (Kg) & 1.296 & 1.319 & 1.357 & 1.392 & 1.425 & 1.475 \\
\hline \multicolumn{7}{|l|}{ Feed cost and economical efficiency: } \\
\hline Cost of feed consumed/head (LE) & 24.455 & 24.041 & 23.651 & 23.177 & 22.547 & 22.492 \\
\hline Price of L.B.W. gain (LE) & 28.512 & 29.018 & 29.854 & 30.624 & 31.350 & 32.450 \\
\hline Feed cost/Kg weight gain (LE) & 18.870 & 18.227 & 17.429 & 16.650 & 15.822 & 15.249 \\
\hline Revenue (LE/head/day) & 4.057 & 4.977 & 6.203 & 7.447 & 8.803 & 9.958 \\
\hline Gross margin above feed cost (LE) & 0.166 & 0.207 & 0.262 & 0.321 & 0.390 & 0.443 \\
\hline Profit (\%) & 16.59 & 20.70 & 26.23 & 32.13 & 39.04 & 44.27 \\
\hline Economical efficiency & 1.166 & 1.207 & 1.262 & 1.321 & 1.390 & 1.443 \\
\hline Improvement of economical efficiency (\%) & -- & 3.52 & 8.23 & 13.29 & 19.21 & 23.76 \\
\hline
\end{tabular}

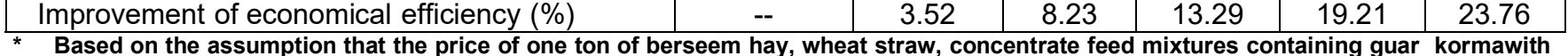
Based on the assumption that the price of one ton of berseem hay, wheat straw, concentrate feed mixtures containing guar kormawith
rate of $0,3.3,6.7,10.0,13.3$ and $16.7 \%$ was $1600,800,2303,2197,2127,2014,1937$ and $1875 \mathrm{LE}$, respectively, and the price of one Kg body weight in selling was 22.00 L.E. 